\title{
MEMPERKUAT MODAL SOSIAL DI KALANGAN UMAT ISLAM PADA ERA POST TRUTH
}

\author{
Oleh: \\ ABDUL RAHMAN ${ }^{1} \&$ ALVIN DWI RAHMAWAN ${ }^{2}$ \\ ${ }^{1}$ Fakultas Ilmu Sosial, Universitas Negeri Makassar, \\ e-mail: abdul.rahman8304@unm.ac.id, ${ }^{2}$ Fakultas Ilmu Sosial dan Ilmu Politik, \\ Universitas Bangka Belitung, e-mail: alfindwirahmawan98@gmail.com
}

\begin{abstract}
ABSTRAK: Indonesia kontemporer dihadapkan pada berbagai macam permasalahan di tengah perkembangan demokrasi. Era globalisasi yang ditandai dengan kemajuan teknologi informasi menjadikan masyarakat dapat menjalin komunikasi secara cepat, dan tidak terikat oleh ruang dan waktu. Akan tetapi, kemajuan dalam bidang teknologi informasi telah memunculkan permasalahan yakni kemunculan sikap saling curiga antara satau kelompok dengan kelompok yang lain, termasuk pada kalangan masyarakat Islam yang berujung pada konflik terbuka. Menghadapi fenomena tersebut, maka disinilah letak pentingnya merajut kembali modal sosial yang ada di kalangan umat Islam agar dapat terjadi hubungan harmonis dengan berbagai kelompok.
\end{abstract}

\section{KATA KUNCI: Modal Sosial, Umat Islam, Era Post Truth}

ABSTRACT: Contemporary Indonesia is faced with various problems in the midst of democratic development. The era of globalization, which is marked by advances in information technology, enables people to establish communication quickly, and is not bound by time and space. However, advancements in the field of information technology have led to the problem of the emergence of mutual suspicion between one group and other groups, including among the Islamic community that led to open conflict. Facing this phenomenon, therein lies the importance of re-knitting the existing social capital among Muslims so that harmonious relations can occur with various groups.

KEY WORDS: Social Capital, Muslims, Post Truth Era

\section{PENDAHULUAN}

Kala itu di pagi hari, tepatnya hari Selasa 21 Mei 1998. Soeharto menyampaikan pidato yang isinya berhenti sebagai Presiden Republik Indonesia yang telah dijabatnya selama 31 tahun 2 bulan 9 hari (Fatah, 2004: 1). Terhitung sejak di pagi hari yang bersejarah itu, 20 tahun kita hidup dalam alam reformasi. Perjalanan sebagai bangsa yang hidup dalam era reformasi telah kita saksikan betapa transisi dari otoritarianisme yang sudah tertanam dan terpelihara lama dan dalam adalah era transisi yang penuh dengan dinamika dan membutuhkan waktu yang lumayan lama, kompleks, dan sukar. Bahkan sampai saat ini, tidak ada yang mampu memberi keyakinan bahwa era reformasi akan menghadirkan Indonesia baru yang gemilang. Masa 20 tahun ini telah menghadirkan kepada publik, betapa para elite dalam lingkaran reformasi tampaknya lebih suka merajut kembali dan bahkan memperluas jaringan dan lingkaran kejahatan kemanusiaan yakni korupsi, kolusi dan nepotisme dan beragam macam pola penyalahgunaan 
kekuasaan, tanpa ada usaha untuk menyelesaikannya.

Putusnya belenggu pengekangan politik yang dilakukan pemerintahan Orde Baru sejak tahun 1998, membuat tahap demokratisasi yang ditandai dengan berlakunya proses liberalisasi demokrasi melesat dijalur cepat pada lintasan pacu politik di Indonesia. Terwujudnya kebebasan bagi kelompok-kelompok yang memiliki hasrat untuk berpolitik sebagai upaya untuk melakukan perjuangan dalam mencapai kekuasaan, berlomba-lomba untuk mendirikan partai politik. Dengan demikian, telah terjadi kemajuan dalam perpolitikan nasional, yakni adanya jaminan kemerdekaan bagi setiap individu memilih sosok yang paling pantas mengemban amanah dan mewakili kedaulatan rakyat (Deannova, 2008: 3). Kemajuan perpolitikan nasional juga ditandai dengan penguatan demokrasi dalam hal kebebasan berpendapat. Warga negara berhak menyatakan pendapat mereka sendiri tanpa adanya bahaya hukuman keras mengenai masalah persamaan politik yang didefinisikan secara luas, termasuk kritik terhadap para pejabat, pemerintah, rezim, tatanan sosial ekonomi, dan ideologi yang ada (Efriza, 2013: 113). Reformasi yang membuka ruang demokrasi telah memunculkan suatu lapisan masyarakat warga (civil society) yang kritis terhadap berbagai penyalahgunaan kekuasaan politik misalnya intoleransi dan korupsi (Hardiman, 2018: 65).

Pada era reformasi, Indonesia berupaya untuk berpisah dengan masa silam otoriternya dan memilih untuk belajar apa yang ada dalam teori politik moderen yang disebut dengan demokrasi. Pemerintah tidak lagi memegang monopoli dalam memberi arah perkembangan masyarakat, maka arah itu tidak lagi ditentukan oleh pemerintah, melainkan oleh demokrasi itu sendiri.
Kebebasan dan kesetaraan merupakan ide yang menggerakkan mereka yang ingin menggantikan rezim, termasuk para aktivis reformasi pada tahun 1998. Pertanyaan Quo Vadis menjadi serba terbuka karena kebebasan dan kesetaraan itu dalam kenyataan tergantung pada kekuatan-kekuatan politis yang ada di Indonesia (Hardiman, 2013: 7).

Salah satu kekuatan politik di Indonesia pada era reformasi ialah media massa. Peran strategis media massa pada era masyarakat informasi menjadi kebutuhan untuk mendorong proses politik bangsa yang bertanggung jawab, terutama sebagai media sosialisasi politik dan kampanye politik. Pergeseran peran media merupakan bentuk transformasi produktif untuk menjadi satu kekuatan politik yang bersinergi dengan lembagalembaga pemerintahan maupun lembaga swadaya masyarakat. Dengan demikian, kehadiran media massa memiliki peranan yang cukup efektif dalam memberikan informasi kepada masyarakat. Media massa hadir untuk meminimalisasi monopoli informasi dari pemerintah dan pihak yang berkuasa. Bahkan pemerintah terkadang bersusah payah untuk menghadapi regulasi liberal mengenai kebebasan informasi publik yang tak terkendali. Muncul permasalahan, media massa semakin besar peranannya, bahkan tidak terkendali dalam menyampaikan informasi dengan cenderung mengabaikan prinsip-prinsip universal yang menjunjung etika sosial (Jurdi, 2016: 302-303).

Media massa di dalam pemerintahan pasca Orde Baru (masa reformasi), telah merefleksikan dinamika, termasuk dinamika politik, yang ada di dalam masyarakat. media massa secara cepat dan luas juga meyiarkan peristiwa-peristiwa penting yang ada di dalam masyarakat tanpa sensor yang cukup sebagaimana di dalam pemerintahan Orde Baru. Acara talk show 
tentang berbagai isu mutakhir ada di mana-mana, baik di televisi maupun radio. Masyarakat bisa aktif memberikan informasi tentang kejadian di sekitarnya, termasuk memberikan kritik terhadap kebijakan-kebijakan yang telah, sedang dan akan dilakukan pemerintah. Media massa telah menjadi bagian penting di dalam kehidupan berdemokrasi. Berbagai peristiwa politik saat ini tidak bisa lagi hanya diketahui dan dikendalikan oleh sekelompok elite di Jakarta. Media massa yang bebas, beragam dan berjumlah banyak, secara mudah menyebarkan informasi tentang berbagai macam peristiwa. Dengan demikian publik memiliki kemudahan untuk memperoleh akses terhadap peristiwa tersebut (Maridjan, 2012: 293-294).

Pergerakan globalisasi di dunia telah menimbulkan pergeseran dalam peran media, baik cetak ataupun elektronik: apa yang harus diberitakan dan bagaimana sikap dan perilaku awak media dalam pencarian dan penyebaran berita. Pergeseran peran media beserta awaknya ini di Indonesia, terutama sejak awal reformasi, juga berimplikasi terhadap nilai-nilai yang dianut oleh pemilik dan pengelola media. Etika pemberitaan tidak sekadar menyangkut apa yang boleh dan tidak boleh dilakukan dalam pencarian dan penyebaran berita, namun juga apa yang baik dan yang buruk, yang bermanfaat dan yang tidak, serta yang pantas atau tidak pantas. Namun semua itu tampaknya tidak saja terikat budaya dan sistem pers yang dianut, namun juga konteks sosial, ruang dan waktu (Mulyana, 2011: iii).

Era informasi yang melanda Indonesia saat ini memudahkan orang bertukar pesan dan berita secara cepat, mudah dan murah. Informasi mudah diproduksi secara bebas oleh siapa saja, disampaikan secara cepat melalui berbagai medium, dan tidak mahal. Di era kemajuan informasi ini, manusia sudah berposisi sebagai produsen sekaligus pengguna dan penikmat informasi. Kemajuan teknologi iformasi ini yang berada pada ruang kebebasan pers sebagai konsekuensi dari perjuangan reformasi telah mendorong munculnya media alternatif. Media alternatif yang dimaksud ialah merujuk pada pengalaman komunikasi yang muncul sebagai sebuah kebutuhan komunitas untuk memenuhi atau memperjuangkan kepentingannya yang termarjinalkan. Media alternatif dipandang sebagai saluran untuk melawan kekuatan atau kemapanan politik (Maryani, 2011: 65).

Kehadiran media alternatif baik cetak maupun elektronik dan diperkuat oleh kehadiran media sosial memunculkan ledakan suplai informasi yang bahkan tidak terbayangkan sebelumnya. Di situs youtube, misalnya lebih dari 60 jam video baru diunggah setiap menit. Sementara di twitter dan facebook bermunculan status dan postingan berita yang melimpah. Informasi yang hadir jauh melebihi kebutuhan publik. Dengan demikian, kita diperhadapkan pada tantangan agar memiliki kemampuan untuk memilah dan memilih informasi yang dibutuhkan dan dapat dipertanggungjawabkan kebenarannya. Publik harus mampu menahan diri untuk mempublikasikan informasi dengan terlebih dahulu mempertimbangkan aspek kemanfaatan dan kemudharatannya (Mulyana, 2015: 149).

Tidak dapat dipungkiri bahwa Penyebaran informasi tanpa mempertimbangkan efek yang akan ditimbulkannya sangat sulit untuk terbendung. Penyebaran informasi dengan mengabaikan aspek-aspek kebenarannya telah menciptakan sebuah era yang dikenal dengan post truth. Era post truth ditandai dengan munculnya banyak pihak secara sengaja memproduksi informasi untuk 
membangkitkan emosi dan menyulut kemarahan dan kebencian terhadap golongan atau kelompok-kelompok tertentu. Post truth juga duwarnai tumbuhnya media abal abal (fake media) yang gencar memproduksi hoax berkolaborasi dengan politisi yang mengabaikan etika. Menurut Atmadja dan Ariani, kehadiran media ibarat dua sisi keping mata uang, pada sisi lain media memberikan kontribusi bagi pembentukan integrasi atau keharmonisan suatu sistem, akan tetapi pada lain sisi media juga dapat memunculkan disintegrasi atau disharmoni pada sebuah sistem baik dalam lingkup komunitas maupun dalam lingkungan kenegaraan bahkan secara global (Atmadja dan Ariyani, 2018: 393). Kemunculan era post truth ini tentunya menjadi tantangan bagi masyarakat Indonesia khususnya kalangan kaum Muslim, karena fakta membuktikan bahwa isu-isu keagamaan memang marak di media yang terkadang memunculkan perselisihan pemahaman antar umat beragama maupun antar umat seagama. Agar persoalan itu tidak memunculkan konflik baik yang bersifat laten maupu manifest maka sudah sepatutnyalah kaum Muslim tampil untuk mengkanalisasi isuisu itu. Salah satu caranya ialah memperkuat modal sosial dalam kehidupan bermasyarakat.

\section{PEMBAHASAN}

Klaim bahwa Islam tidak sejalan dengan demokrasi sebagian didasarkan pada proposisi bahwa masyarakat kewargaan adalah sesuatu yang asing dalam Islam (Muzani, 2007: 117). Akan tetapi klaim tersebut dijelaskan secara cermat oleh Saiful Muzani bahwa modal sosial memiliki arti penting dalam mewujudkan kehidupan yang harmonis, sebagaimana yang dicita-citakan bahkan diwajibkan dalam ajaran Islam. Doktrin
Islam mengharuskan kepada pemeluknya untuk senantiasa berbakti dan mengabdi kepada Allah, menjalin hubungan yang harmonis dengan sesama manusia maupun terhadap alam semesta yang terdiri atas tumbuhan dan hewan. Islam pun mengajarkan untuk senantiasa memelihara hubungan sesama manusia secara global, hubungan persaudaraan yang diikat oleh negara bangsa dan hubungan yang diikat oleh kesamaan agama.

Secara umum, modal sosial merupakan salah satu elemen penting yang ada dalam kehidupan masyarakat dalam bentuk norma dan nilai yang menfasilitasi dan mengembangkan kerjasama melalui jaringan interaksi dan komunikasi yang harmonis dan kondusif. Definisi modal sosial secara sederhana menurut Fukuyama adalah "an instantiated informal norm that promotes co-operation between two or more individuals. By this definition, trust, networks, civil society, and the like, which have been associated with social capital, are all epiphenominal, arising as a result of social capital but not constituting social capital itself'. Modal sosial memiliki peran yang sangat penting pada beberapa kelompok masyarakat dalam berbagai aktivitas. Namun Fukuyama juga mengatakan bahwa tidak semua norma, nilai dan budaya secara bersama-sama dapat saling melengkapi untuk mendukung pertumbuhan ekonomi. Sama seperti halnya modal fisik dan modal finansial, modal sosial juga bisa menimbulkan dampak negatif. Fukuyama mengatakan bahwa modal sosial dibangun oleh kepercayaan-kepercayaan antar individu. Rasa saling percaya dibentuk dalam waktu yang tidak sebentar serta memerlukan proses-proses sosial yang berliku (.http://acil10111. blogspot.com/2014/04/definisi-modalsosial-menurut-para-ahli.html) 
Kehadiran kapitalisme dalam pandangan Francis Fukuyama telah memunculkan longgarnya ikatan modal sosial. Kapitalisme yang lahir dari peradaban Barat merupakan titik puncak dari berbagai peristiwa yang melanda Eropa. Kapitalisme berawal dari adanya gerakan keagamaan yang dipelopori oleh Marthen Luther sebagai bentuk protes terhadap kekuasaan gereja katolik yang mendominasi kehidupan masyarakat Eropa. Gerakan tersebut menghantarkan masyarakat Eropa memasuki zaman yang dikenan dengan zaman pencerahan. Eropa mengalami kemajuan berpikir yang berujung pada kemajuan ilmu pengetahuan dan teknologi. Salah satu kemajuan yang dicapai ialah ditemukannya kompas sebagai penakluk ruang dan mesiu sebagai penakluk orang. Kemajuan yang dialami oleh Bangsa Eropa melahirkan doktrin imperialisme yang berintikan usaha untuk memperoleh kekayaan, kejayaan, dan semangat menyebarkan agama. Dari doktrin inilah bangsa Eropa melakukan penjelajahan samudra, dan ketika mereka tiba pada suatu tempat di sanalah mereka menjalankan usaha untuk memperoleh keuntungan.

Kapitalisme terus mengalami perkembangan yang cukup pesat. Berbagai macam upaya ditempuh untuk mencapai keuntungan. Kapitalisme tidak lagi ditandai dengan kegiatan perdagangan antar negara, tetapi juga ditandai dengan kemajuan berbagai media baik cetak maupun elektronik. Berbagai macam temuan-temuan baru dalam bidang teknologi informasi dan komunikasi yang telah memudahkan masyarakat untuk melakukan komunikasi satu sama lain. Media pun telah memiliki kuasa untuk memproduksi dan menyebarkan informasi tanpa mempertimbangkan asas-asas kebenaran dan etika. Berbagai macam peristiwa yang terjadi di belahan bumi begitu cepatnya dapat dinikmati oleh seluruh masyarakat.

Dalam konteks tersebut, wajar bila kehidupan masyarakat moderen tampil dengan wajah yang antagonistik. Di satu pihak, modernisme dan kapitalisme tealh menyumbangkan kemajuan spektakuler dalam takaran material. Namun pada sisi lain, paradigma tersebut benar-benar memburamkan wajah kemanusiaan. Semakin maju sains dan teknologi, seolah-olah menjadikan manusia tidak memerlukan spiritualitas, agama, dan bahkan Tuhan. Secara arogan dan despotik, manusia merasa mampu menyelesaikan segala tantangan zaman, termasuk hari depan yang sejatinya tak pernah tersingkapkan (Arifin, 2019: 160).

Kemajuan ilmu pengetahuan dan teknologi dalam memproduksi dan menyebarkan informasi ke berbagai belahan dunia, mengantarkan manusia memasuki era pasca kebenaran (post truth). Dalam pandangan Grayling, era post-truth bukan saja penuh aroma narsistik, tapi sekaligus narsistik yang mengerikan. Ketika media apapun dapat dipakai untuk mengirim pesan yang lebih menonjolkan opini ketimbang fakta, dan setiap orang bisa mempublikasikan opininya sendiri, maka fakta apapun akan tenggelam oleh kerasnya suara pengirim pesan. Setiap orang dapat menerbitkan opininya, setiap orang menawarkan tafsirnya sendiri terhadap fakta, danyang paling repot-setiap orang mengklaim bahwa tafsirnya yang paling benar. Opini inilah yang diangkat sebagai 'kebenaran', bukan faktanya (https://indonesiana.tempo.co/read/1071

84/2017/01/24/desibelkoe/era-posttruth-kebenaran-jadi-komoditas).

Memasuki era post truth ada berbagai macam persoalan yang dihadapi baik sebagai warga negara maupun sebagai kelompok Islam. Pertama, kekacauan lingkungan internasional yang 
ditandai dengan pertentangan bahkan konflik terbuka antar negara, khususnya negara-negara yang masyarakatnya beragama Islam di Kawasan Timur Tengah. Konflik klasik yang melibatkan antara Israel dan Palestina semakin rumit karena telah menyeret negara-negara di sekitarnya untuk masing-masing memberikan pembelaan terhadap salah satu di antara keduanya. Kedua, menguatnya radikalisme dan takfirisme. Dalam arena Indonesia, bangkitnya aksiaksi radikalisme tidak dapat dipisahkan dari kelompok-kelompok Islam garis keras. Menurut Abdurrahman Wahid (2011: 143) pada umumnya aspirasi kelompok-kelompok garis keras di Indonesia dipengaruhi oleh gerakan Isalm transnasional dari Timur Tengah, terutama yang berpaham Wahabi atau Ikhwanul Muslimin, atau gabungan keduanya. Kelompok-kelompok garis keras di Indonesia, termasuk partai politiknya, menyimpan agenda yang berbeda dengan ormas-ormas Islam moderat seperti NU dan Muhammadiyah. Dalam beberapa tahun terakhir sejak kemunculannya, kelompok-kelompok Islam garis keras telah berhasil mengubah wajah Islam Indonesia menjadi agresif, beringas, intoleran dan penuh kebencian. Kelompok Islam garis keras juga diikuti dengan takfiri. Takfiri dimaksudkan sebagai kelompok yang menjadikan Islam sebagai ideologi, sehingga keagungan Islam sebgaia agama justru dijadikan sebagai alat untuk mencapai tujuan-tujuan politik. Islam dijadikan sebagai senjata politik untuk menyerang kelompok-kelompok lain yang memiliki pandangan dengan mereka. Islam dijadikan sebagai jargon untuk memperjuangkan umat, padahal di balik itu mereka menjadikan Islam sebagai kemasan dan senjata.

Permasalahan ketiga yang dihadapi oleh manusia dalam era post truth ialah penyalahgunaan teknologi informasi. Kemajuan teknologi informasi membuat dunia semakin sempit dalam konteks interaksi. Teknologi informasi telah membuka sekat-sekat antar negara, sehingga para warga negara dapat dengan bebas berinteraksi secara cepat. Demikian halnya penyebara informasi baik yang berupa fakta maupun kebohongan dapat tersebar dengan cepat. Ketika informasi yang berupa kebohongan telah menyebar kepada mereka yang miskin literasi dalam bermedia, maka hal tersebut dapat memunculkan konflik antar kelompok, sebab dalam teori konspirasi diyakini bahwa konflik yang terjadi di suatu tempat tidak dapat dinafikkan bahwa ada kelompok-kelompok tertentu yang menjadi dalang profokasi.

Pada era post truth, masyarakat Indonesia juga turut merasakan dampaknya. Sebagian masyarakat Indonesia dikenal sebagai penikmat media sosial yang paling cerewet dalam menulis status, memposting berita, akan tetapi paling malas melakukan kritik terhadap berita-berita yang beredar. Berita-berita yang hadir di laman facebook mereka dengan begitu cepat dan gampangnya dibagikan sehingga orang lain pun membacanya. Pertimbanganpertimbangan yang sifatnya mencari kebenaran berita tidak lagi diperhatikan. Kebenaran suatu berita tidak lagi menjadi perhatian utama, melainkan aspek kepentingan, dalam arti yang penting berita itu sesuai dengan pikiran dan pilihan atau orientasi politiknya.

Masih segar dalam ingatan kita mengenai aksi pembakaran yang diklaim oleh sekelompok umat Islam sebagai bendera tauhid dalam peringatan hari santri nasional. Aksi tersebut dengan cepatnya menuai pro dan kontra di kalangan umat Islam. Laman facebook diwarnai dengan perdebatan antara satu dengan yang lain. Dalam suatu kesempatan pada acara dialog dalam 
sebuah televisi swasta, Al Muzammil Yusuf, seorang petinggi PKS menyatakan bahwa kalimah tauhid itu memang merupakan hal yang sakral di kalangan umat Islam, sehingga peristiwa yang memiliki kaitan dengan kalimah tauhid itu, misalnya aksi pembakaran akan mudah dipolitisir segingga menyulut kemarahan sebagian umat Islam. Oleh karena itu sudah sepatutnyalah proses hukum segera dilaksanakan dan umat Islam tetap menjaga diri jangan sampai ada pihak-pihak yang sengaja membenturkan umat Islam dan berupaya mencari keuntungan di balik peristiwa itu.

Umat Islam dalam menjalani kehidupan pada era post truth dituntut untuk memperkuat kembali modal sosial yang telah digariskan pada sumber uatama ajarannya yaitu Alquran dan Hadist. Kaum Muslim telah memiliki fondasi yang kokoh untuk mewujudkan tatanan masyarakat yang harmonis. Islam memiliki komitmen untuk taat terhadap perjanjian, norma, nilai yang telah disepakati secara bersama. Perjalanan sejarah Umat Islam pada 15 abad yang lampau membuktikan bahwa umat Islam mampu hidup berdampingan secara damai dengan pemeluk agama Nasrani dan Yahudi dalam bingkai negara Madinah. Pada masa itu masyarakat Madinah diajarkan untuk membina dan mengedepankan masyarakat ideal yang acapkali disebut sebagai masyarakat madani, masyarakat yang menjunjung tinggi nilai-nilai keadaban. Masyarakat yang memiliki tatanan sosial yang baik, berasas pada prinsip moral yang menjamin keseimbangan antara hak dan kewajiban individu dengan hak dan kewajiban sebagai warga masyarakat (Rosyadi, 2011: 52).

Prinsip ajaran Islam yang kompatibel dengan modal sosial yang berfungsi sebagai perekat kehidupan sosial kemasyarakatan ialah Islam sebagai rahmah, rahmah bagi seluruh alam semesta (Islam rahmatan lil alamin). Doktrin tersebut sangat jelas disampaikan oleh Allah kepada Muhammad yang tertuang dalam Alquran, Surah Al anbiya ayat 107 bahwa: "tidaklah kami mengutusmu wahai Muhammad kecuali sebagai rahmat bagi seluruh alam semesta". Atas dasar doktrin itulah, maka sepatutnyalah umat Islam untuk menyebarkan emansipasi kemanusiaan terhadap seluruh umat manusia tanpa membedakan suku, agama, ras dan adat (SARA). Pengutusan Muhammad sebagai nabi dan rasul merupakan bukti kasih sayang Allah terhadap seluruh alam semesta. Akan tetapi, perlu dipahami bahwa kasih sayang yang dimaksud bukanlah mengasihi segala sesuatu yang mengandung unsur kemungkaran. Kasih sayang yang sesuai dengan pesan Alquran ialah memberikan perlindungan dan kebebasan kepada pemeluk agama lain untuk menjalankan ibadahnya.

Modal sosial dalam bentuk lain dalam doktrin Islam ialah ta'awun. Hal ini jelas diterangkan oleh Allah dalam Alquran surah almaidah, penggalan ayat 2 bahwa Dan tolong-menolonglah kamu dalam (mengerjakan) kebajikan dan takwa, dan jangan tolong-menolong dalam berbuat dosa dan pelanggaran. Dan bertakwalah kamu kepada Allah, sesungguhnya Allah amat berat siksaNya. Bertolak dari doktrin tersebut maka prinsip ta'awun dalam Islam ialah saling tolong menolong dalam kebaikan antar sesama manusia tanpa memandang perbedaan. Jika sikap ta'awun telah dilaksanakan oleh seluruh umat manusia, khususnya umat Islam, maka kehidupan bermasyarakat akan menjadi harmonis dan sejahtera, tidak akan ada lagi orangorang yang merasakan ketidakadilan. Jika seluruh masyarakat sudah mengalami kesejahteraan dan diperlakukan secara adil, maka dengan sendirinya riak-riak 
yang akan berujung pada aksi protes akan mudah diatasi. Berita-berita propaganda yang mengadu antara sesama warga akan dapat diminimalisir.

Hal lain yang harus dikedepankan oleh umat Islam dalam memelihara keharmonisan sosial di era post truth ialah tabayyun. Sikap ini penting demi menghindari fitnah dan kebencian terhadap kelompok atau individu. Sebab, dengan kemajuan teknologi, pernyataan seseorang akan sangat gampang dipenggal atau tidak ditampilkan secara utuh. Hal ini pernah melanda Quraish Shihab sewaktu menjelaskan sebuah hadist pada tayangan Tafsir Almisbah. Dalam acara tersebut dia mengutip hadist nabi yakni: "Tidak seorang pun masuk surga karena amalnya. Sahabat bertanya "Engkau pun tidak?", beliau menjawab "Saya pun tidak, kecuali berkat rahmat Allah kepadaku." Kutipan tersebut kemudian dipelintir oleh beberapa media bahwa Quraish Shihab salah menafsirkan dalil karena menyatakan bahwa Nabi Muhammad tidak dijamin masuk surga.

Prinsip tabayyun diperkuat oleh Majelis Ulama Indonesia dalam bermedia sosial. dalam Fatwa MUI No. 24 tahun 2017 tentang Hukum dan Pedoman Bermuamalah Melalui Media Sosial, diatur mekanisme atau tahapan dalam melakukan tabayyun. Proses tabayyun terhadap konten atau informasi dilakukan melalui tiga tahap, pertama, memastikan aspek sumber informasi, yang meliputi kepribadian, reputasi, kelayakan dan keterpercayaannya. Kedua, memastikan aspek kebenaran konten, yang meliputi isi dan maksudnya. Ketiga, memastikan konteks tempat dan waktu serta latar belakang saat informasi tersebut disampaikan. Selain itu, fatwa MUI tersebut juga mencantumkan cara untuk memastikan kebenaran informasi, yakni bertanya kepada sumber informasi jika diketahui dan permintaan klarifikasi kepada pihak-pihak yang memiliki otoritas dan kompetensi. Dengan demikian, ketika ajaran Islam dapat diterapkan dalam kehidupan berbangsa dan bernegara maka Indonesia bisa menjadi model bagi hubungan antara Islam dan Negara yang sesuai dengan nilai-nilai Islam di satu sisi, dan kebangsaan moderen pada sisi lain (Arif, 2009: 193).

\section{PENUTUP}

Dipahami bahwa setiap agama membentuk solidaritas kelompok berbasis kesamaan agama. Hal tersebut merupakan suatu kewajaran karena agama membentuk umat, dan umat tersebut bersatu dalam kesatuan kebenaran. Maka membela umat seagamanya terkadang lebih penting ketimbang membela umat agama lain. Dalam kondisi inilah terjadi ketegangan antara kebangsaan yang bersifat nasional, dan keumatan yang universal. Perbedaan dalam menyikapi kebangsaan dan keumatan semakin mencolok ketika media hadir melakukan propaganda demi memperoleh rating. Isu-isu yang sensitif semakin diberi porsi yang besar dalam penayangannya bahkan dilakukan secara berulang-ulang. Menghadapi kondisi yang demikian, maka kaum Muslim yang merupakan golongan mayoritas dan salah satu kekuatan politik di Indonesia harus semakin bijak dalam menyikapi berbagai isu, baik itu isu kebangsaan maupun isu keagamaan. Sudah saatnya Umat Islam di negara ini tampil memberikan pencerahan dan melakukan kanalisasi terhadap isu-isu yang dapat memunculkan disharmoni sesama anak bangsa. Modal sosial yang terkandung dalam pesan-pesan maupun doktrin keagamaan berupa rahmah, ta'awun, dan tabayyun harus disebarkanluaskan sebagai perekat persaudaraan di era post truth. 
DAFTAR PUSTAKA

Arif, Syaiful . Islam, Pancasila dan Deradikalisasi. Jakarta: Elex Media Komputindo.

Arifin, Syamsul. 2019. Populisme, Demokratisasi, Multikulturalisme. Malang: Intras Publishing.

Atmadja, Nengah Bawah dan Luh Putu Sri Ariyani. 2018. Sosiologi Media Perspektif Teori Kritis. Jakarta: Rajawali Pers.

Deannova, Alvito Deannova. 2008. Selebriti Mendadak Politisi: Studi Atas Pragmatisme Kaum Selebriti Dari Panggung Hiburan Menuju Panggung Politik. Yogyakarta: Arti Bumi Intaran.

Efriza. 2013. Ilmu Politik: Dari Ilmu Politik Sampai Sistem Pemerintahan. Bandung: Alfabeta.

Fatah, Eep Saefulloh. 2004. Mencintai Indonesia Dengan Amal. Jakarta: Republika.

Hardiman, F. Budi. 2013. Dalam Moncong Oligarki: Skandal Demokrasi di Indonesia. Yogyakarta: Kanisius.

Hardiman, F. Budi. 2018. Demokrasi dan Sentimentalis. Yogyakarta: Kanisius

Jurdi, Syarifuddin Jurdi. 2016. KekuatanKekuatan Politik Indonesia. Jakarta: Kencana.

Maridjan, Kacung Maridjan. 2012. Sistem Politik Indonesia:
Konsolidasi Demokrasi Pasca Orde Baru. Jakarta: Kencana.

Maryani, Eni. 2011. Media dan Perubahan Sosial. Bandung: Rosda.

Mujani, Saiful. 2007. Muslim Demokrat. Jakarta: Gramedia.

Mulyana, Deddy Mulyana. 2011. "Membangun Media yang Kritis" dalam Eni Maryani, Media dan Perubahan Sosial. Bandung: Rosda.

Mulyana, Deddy Mulyana dkk. 2015. Komunikasi Media dan Masyarakat. Bandung: Rosda.

Rosyadi, Khoirul. Islam, Modal Sosial, Pembangunan dan Pengentasan Kemiskinan.

Wahid, Abdurrahman. 2011. Sekadar Mendahului. Bandung: Nuansa.

http://acil10111.blogspot.com/2014/04/d efinisi-modal-sosial-menurutpara-ahli.html. Diakses pada, Kamis, 01 November 2018, pukul 21:34 WITA.

https://indonesiana.tempo.co/read/10718 4/2017/01/24/desibelkoe/erapost-truth-kebenaran-jadikomoditas. Diakses pada, Kamis 01 November 2018, pukul 22.08 WITA.

https://nasional.kompas.com/read/2017/0 6/09/17130471/mui.tabayyun.pr insip.muamalah.medsosiah. diakses pada, Kamis 01 November 2018, pukul 23.48 Wita. 